\title{
Evaluasi Sistem Budidaya Tanaman Asystasia gangetica T. Anderson yang Ditanam dengan Jarak Berbeda di Bawah Naungan Kelapa Sawit
}

\author{
Herilimiansyah¹, NR Kumalasari1*, L Abdullah¹
}

Corresponding email:

nurrkumala@gmail.com

'Department of Animal Nutrition and Feed Technology, Faculty of Animal Science, IPB University

(Bogor Agricultural University)

\section{ABSTRACT}

The objective of this experiment was to evaluate the cultivation, production and quality systems of Asystasia gangetica T. Anderson as forage in palm oil plantations. This research was arranged in a factorial randomized block design with 2 factors, i.e. palm plantation ages ( 6 and 8 years old) and different plant spacing $(10 \times 10 \mathrm{~cm}$, $25 \times 25 \mathrm{~cm}$, and $40 \times 40 \mathrm{~cm}$ ). Variables observed were plant height, number of leaves, number of primary and secondary branches, leaf length and width, biomass production, and nutrient contents. Spacing was significantly affected $(\mathrm{p}<0.05)$ on increasing height plant, number of primary and secondary branches, number of leaves, leaf width and length, and biomass production. The spacing also has a significant effect $(\mathrm{p}<0.05)$ on nutrient content such as dry matter and crude fiber. The heighest plants average at plant spacing of $10 \times 10 \mathrm{~cm}$ was $66.19 \mathrm{~cm}$, the best number of primary and secondary branches at spacing of $25 \times 25 \mathrm{~cm}$ were 2 and 10 branches, the average number of the best number of leaves at spacing of $25 \times 25 \mathrm{~cm}$ was 80 leaflets, leaveslength and width at spacing of $10 \times 10 \mathrm{~cm}$ were 12.49 and 4.29 $\mathrm{cm}$, while the best biomass production at spacing of $10 \times 10 \mathrm{~cm}$ was $2766 \mathrm{~g}$. The research concluded that in order to obtain high crop production, the best plant spacing was $10 \times 10 \mathrm{~cm}$ under 6 years old of palm plantation, whereas the best nutrient quality was on $25 \times 25 \mathrm{~cm}$ spacing.

Keywords: Asystasia, biomass, forage, nutrient content, plant spacing

\section{ABSTRAK}

Tujuan penelitian ini adalah untuk mengevaluasi sistem budidaya, produksi dan kualitas tanaman Asystasia gangetica T. Anderson sebagai hijauan pakan di perkebunan kelapa sawit. Rancangan percobaan yang digunakan pada penelitian ini adalah Rancangan Acak Kelompok Faktorial. Faktor pertama adalah penaung yaitu kelapa sawit umur 6 tahun dan 8 tahun dan faktor kedua jarak tanam yaitu $10 \times 10 \mathrm{~cm}, 25 \times 25 \mathrm{~cm}$ dan $40 \times 40 \mathrm{~cm}$. Setiap jarak tanam masing-masing diulang sebanyak 3 kali. Peubah yang diamati dalam penelitian ini adalah tinggi tanaman, jumlah daun, panjang daun, lebar daun, jumlah cabang primer, jumlah cabang sekunder, produksi segar, kualitas nutrien dan kadar serat ADF dan NDF. Hasil penelitian menunjukkan jarak tanam 10x10 cm lebih baik pada tinggi, lebar dan luas daun sedangkan jarak tanam $25 \times 25 \mathrm{~cm}$ memberikan pengaruh yang baik pada cabang primer, sekunder dan jumlah daun. Produksi tertinggi diperoleh pada jarak tanam 10x10 cm, kualitas nutrien terbaik didapatkan pada jarak tanam 40x40 cm dan kadar serat terbaik diperoleh pada jarak 10x10cm. Dapat disimpulkan bahwa A. gangetica tumbuh dengan baik di bawah naungan kelapa sawit umur 6 tahun dibandingkan dengan naungan kelapa sawit umur 8 tahun. Produksi terbaik terdapat pada jarak tanam $10 \times 10 \mathrm{~cm}$ pada naungan kelapa sawit umur 6 tahun, sedangkan kualitas nutrien yang terbaik terdapat pada jarak tanam $25 \times 25 \mathrm{~cm}$.

Kata kunci: Asystasia, biomassa, hijauan, jarak tanam, nutrien 


\section{PENDAHULUAN}

Perkebunan memiliki potensi sebagai sumber pakan hijauan dengan adanya area yang kosong ditumbuhi oleh hijauan. Petani melakukan pola integrasi untuk mengefisienkan penggunaan lahan antara tanaman pertanian dan hijauan pakan (Homann-Kee et al. 2015). Salah satu perkebunan yang berpotensi untuk diintegrasikan dengan peternakan adalah perkebunan kelapa sawit. Daru et al. (2013) menyatakan bahwa keberadaan ternak di perkebunan kelapa sawit memberikan beberapa keuntungan seperti mengurangi biaya pengendalian gulma dan feses sapi sebagai sumber hara bagi tanaman. Luas perkebunan kelapa sawit yang ada di Indonesia saat ini mencapai 12.307.677 ha (Statistik Perkebunan Indonesia 2017). Terdapatnya potensi luas lahan tersebut, berpeluang hijauan (gulma) dapat tumbuh di bawah naungan atau sela diantara pohon kelapa sawit.

Salah satu gulma yang dapat dimanfaatkan sebagai pakan ternak dan tahan naungan yaitu Asystasia gangetica T. Anderson atau Ara Sungsang. A. gangetica di perkebunan kelapa sawit memiliki kecepatan tumbuh yang baik. A. gangetica di perkebunan kelapa sawit mampu menghasilkan biji dalam jumlah banyak dengan sifatnya yang invasif sehingga mudah berkecambah dan mendominasi lahan kosong yang ada di perkebunan kelapa sawit. A. gangetica mampu tumbuh dari pangkal ruas -ruas batang saat menyentuh tanah (Priwiratama 2011) dan dalam waktu 6 minggu telah berbunga dan menghasilkan biji (Adetula 2004).

Kombinasi antara $A$. gangetica dengan kelapa sawit dewasa lebih efektif di lahan miring untuk menurunkan tingkat erosi dan mencegah hilangnya bahan organik tanah C, N, P dan K dengan kisaran 94,1\%; 99,1 \%; 99,2\%; 90\% dan 98,5\% (Asbur et al. 2016). A. gangetica memiliki kandungan antioksidan yang tinggi sehingga mampu dijadikan obat (Gopal et al. 2013; Mugabo \& Raji 2013), sebagai pakan ternak ruminansia karena kandungan nutriennya yang tinggi (Adetula 2004) dan dapat digunakan sebagai tanaman penutup tanah di kebun kelapa sawit karena tidak mempunyai sulur dan duri (Sandoval dan Rodriguez 2012). Menurut Asbur et al. (2015) bahwa dengan jarak tanam $10 \times 10 \mathrm{~cm}$, A. gangetica sangat baik dijadikan cover crop dengan tutupan lahan sebesar 98,67\%. Kemampuan A. gangetica menutup lahan perlu dikaji lebih lanjut produksi dan kualitas sebagai hijauan pakan. Penelitian ini bertujuan untuk mengevaluasi pertumbuhan, produksi dan kualitas tanaman A. gangetica pada jarak tanam yang berbeda untuk menghasilkan sebagai hijauan pakan berkualitas di perkebunan kelapa sawit.

\section{METODE}

Alat yang digunakan dalam penelitian ini yaitu alat ukur (mistar dan meter), alat rekam data (pulpen dan buku), gunting, timbangan, kalkulator, cangkul, bor tanah, polybag, nampan pengering sampel tanah, ayakan, dan wadah sampel. Penelitian ini menggunakan stek tanaman A. gangetica, zat pengatur tumbuh (ZPT) auksin, aquades, pupuk kandang, pita berwarna, kantong sampel, pupuk kandang, dan tanah.

\section{Prosedur Penelitian}

Stek dengan 2 buku diambil dari tanaman $A$. gangetica kemudian direndam dalam zat pengatur tumbuh (ZPT) auksin 25 ppm selama 15 menit. Stek ditanam dalam polybag dengan media tanam campuran tanah dan pupuk kandang dengan perbandingan 2:1 dicampur rata. Bibit dirawat di bawah paranet $25 \%$ selama 21 hari.

Lahan di area perkebunan kelapa sawit dibersihkan dari tumbuhan lain. Selanjutnya, bibit dipindahkan ke lubang tanam dengan jarak tanam $10 \times 10 \mathrm{~cm}, 25 \times 25 \mathrm{~cm}$ dan $40 \times 40 \mathrm{~cm}$ dalam petak ukuran $2 \times 2 \mathrm{~m}$ diantara sela pohon kelapa sawit (gawangan). Jumlah petak yang digunakan dalam penelitian ini adalah 18 petak. Tanaman di panen pada umur 50 hari setelah penanaman dengan ketinggian $10 \mathrm{~cm}$ dari permukaan tanah.

Peubah yang diukur dalam penelitian ini adalah tinggi tanaman; jumlah daun; jumlah cabang primer dan cabang sekunder; panjang dan lebar daun (3 lembar yang paling lebih panjang dan lebar); produksi segar (pemotongan \pm $10 \mathrm{~cm}$ di atas permukaan tanah); analisis kadar abu, lemak kasar, protein kasar dan serat kasar dengan metode analisis proksimat sesuai AOAC (2005); analisis kadar Acid Detergent Fiber (ADF) (Goering and Van Soest 1970) dan Nitrogen Detergent Fiber (NDF) (Van Soest et al. 1991).

\section{Analisis Data}

Rancangan percobaan yang digunakan pada penelitian ini adalah Rancangan Acak Kelompok Faktorial. Faktor pertama adalah penaung yaitu kelapa sawit umur 6 tahun dan 8 tahun dan faktor kedua jarak tanam yaitu $10 \times 10 \mathrm{~cm}$, $25 \times 25 \mathrm{~cm}$ dan $40 \times 40 \mathrm{~cm}$, masing- masing perlakuan diulang sebanyak 3 kali.

Analisis data dilakukan dengan menggunakan analisis sidik ragam, jika terdapat pengaruh yang nyata maka akan diuji lanjut dengan menggunakan uji LSD. Analisis data menggunakan software statistik R.3.2.

\section{HASIL DAN PEMBAHASAN}

\section{Pertumbuhan A. gangetica}

Jarak tanam berpengaruh nyata $(\mathrm{p}<0,05)$ terhadap tinggi tanaman A. gangetica. Rataan tinggi tanaman pada masing - masing perlakuan adalah 66,19 cm; 57,46 cm dan $43,17 \mathrm{~cm}$. Jarak tanam yang menghasilkan tinggi tanaman terbaik terdapat pada perlakuan $10 \times 10 \mathrm{~cm}$ dan rataan tinggi terendah terdapat pada perlakuan $40 \times 40 \mathrm{~cm}$ (Tabel 1). Semakin rapat jarak tanam maka tinggi 
Tabel 1 Pengaruh jarak tanam terhadap pertumbuhan A. gangetica

\begin{tabular}{|c|c|c|c|c|c|c|}
\hline \multirow{2}{*}{ Perlakuan } & \multicolumn{6}{|c|}{ Morfologi Tanaman } \\
\hline & Tinggi $(\mathrm{cm})$ & n Cabang Primer & n Cabang Sekunder & n Daun & Panjang Daun $(\mathrm{cm})$ & Lebar Daun (cm) \\
\hline \multicolumn{7}{|c|}{ Jarak Tanam (cm) } \\
\hline $10 \times 10$ & $66,19 \pm 12,20^{a}$ & $2,10 \pm 0,47^{b}$ & $5,03 \pm 3,62^{b}$ & $34,80 \pm 16,86^{c}$ & $12,49 \pm 1,60^{a}$ & $4,29 \pm 0,53^{a}$ \\
\hline $25 \times 25$ & $57,46 \pm 15,40^{b}$ & $2,40 \pm 0,80^{a}$ & $10,53 \pm 6,32^{a}$ & $80,07 \pm 47,78^{a}$ & $10,91 \pm 1,81^{b}$ & $4,02 \pm 0,53^{b}$ \\
\hline $40 \times 40$ & $43,17 \pm 9,74^{c}$ & $2,00 \pm 0,36^{b}$ & $4,22 \pm 3,62^{b}$ & $38,67 \pm 19,35^{b}$ & $10,81 \pm 1,96^{b}$ & $4,09 \pm 0,65^{b}$ \\
\hline \multicolumn{7}{|l|}{ Umur Sawit } \\
\hline 6 tahun & $61,52 \pm 14,14^{a}$ & $2,24 \pm 0,62^{a}$ & $9,56 \pm 5,37^{\mathrm{a}}$ & $69,96 \pm 41,56^{a}$ & $12,16 \pm 1,70^{\mathrm{a}}$ & $4,35 \pm 0,49^{a}$ \\
\hline 8 tahun & $49,69 \pm 15,17^{b}$ & $2,08 \pm 0,57^{a}$ & $3,72 \pm 3,76^{b}$ & $32,38 \pm 18,2^{b}$ & $10,64 \pm 1,88^{b}$ & $3,91 \pm 0,57^{b}$ \\
\hline
\end{tabular}

$n=$ jumlah, Superskrip yang berbeda pada kolom yang sama menunjukkan perbedaan nyata $(P<0,05)$

tanaman semakin tinggi. Tinggi tanaman ini dipengaruhi oleh kerapatan antar individu sehingga tidak memiliki area untuk tumbuh merambat. Alvarez et al. (2006), dan Demétrio et al. (2008) menyatakan peningkatan tinggi tanaman karena jarak tanam yang sempit. Menurut Kumalasari et al. (2017), jarak tanam dan jumlah individu berpengaruh pada perkembangan tumbuhan.

Jarak tanam berpengaruh nyata $(\mathrm{p}<0,05)$ terhadap pertambahan jumlah cabang primer $A$. gangetica. Jumlah cabang terbanyak terdapat pada perlakuan $25 \times 25 \mathrm{~cm}$ (Tabel1) karena kurangnya persaingan dan sifat dari $A$. gangetica yang hidup berkelompok. Hal ini berpengaruh juga terhadap perkembangan cabang sekunder. Menurut Banurea etal. (2017), pembentukan cabang dan produksi daun oleh tanaman dengan menggunakan hasil simpanan fotosintat.

Jarak tanam berpengaruh nyata $(\mathrm{p}<0,05)$ terhadap pertambahan jumlah daun $A$. gangetica. Jumlah daun tertinggi terdapat pada perlakuan $25 \times 25 \mathrm{~cm}$ sedangkan terendah terdapat pada perlakuan $10 \times 10 \mathrm{~cm}$ (Tabel 1). Menurut Priwiratama (2011), A. gangetica mampu tumbuh dari pangkal ruas -ruas batang saat menyentuh tanah. Bagian tanaman yang menyentuh tanah akan tumbuh dan membentuk cabang baru tempat tumbuh daun.

Jarak tanam juga berpengaruh nyata $(\mathrm{p}<0,05)$ terhadap panjang daun dan lebar daun A. gangetica. Panjang dan lebar daun perlakuan $10 \times 10 \mathrm{~cm}$ lebih baik dibandingkan dengan perlakuan lainnya (Tabel 1). Hal ini disebabkan karena jarak tanam yang pendek sehingga tanaman berkompetisi dalam memperoleh cahaya sehingga daun dari tanaman akan melebar untuk menangkap cahaya sebagai respon untuk mempertahankan hidup.

Umur kelapa sawit berpengaruh nyata $(p<0,05)$ terhadap pertumbuhan tinggi, cabang primer, cabang sekunder, jumlah daun, panjang daun dan lebar daun tanaman A. gangetica. Rataan pertumbuhan morfologi tanaman A. gangetica lebih tinggi pada perlakuan naungan umur 6 tahun dibandingkan pada naungan umur 8 tahun (Tabel 1). Kemampuan pertumbuhan tanaman $A$. gangetica pada umur 6 tahun dapat dipengaruhi naungan yang memiliki tingkat intensitas cahaya lebih tinggi dibandingkan dengan naungan umur 8 tahun. Karima et al. (2013), faktor penghambat pertumbuhan dan produksi tanaman adalah adanya persaingan akan kebutuhan cahaya matahari untuk proses fotosintesis. Sari et al. (2016) menyatakan kompetisi cahaya dipengaruhi oleh beberapa faktor yaitu bentuk daun, luas tajuk dan tinggi tanaman

\section{Produksi Biomassa}

Berat segar dalam penelitian ini diambil dari hasil pemotongan tanaman pada setiap plot kemudian ditimbang. Jarak tanam dan umur kelapa sawit berpengaruh nyata $(\mathrm{p}<0,05)$ terhadap produksi berat segar tanaman A.gangetica.

Jarak tanam terbaik adalah pada perlakuan $10 \times 10 \mathrm{~cm}$ yang memiliki produksi tertinggi jika dibandingkan dengan perlakuan lainnya (Tabel 2). Hal ini disebabkan karena jumlah individu tanaman pada perlakuan ini lebih banyak dibandingkan dengan perlakuan lainnya .

A. gangetica pada naungan kelapa sawit berumur 6 tahun memproduksi biomassa lebih tinggi dibandingkan umur 8 tahun. Hal ini karena pada naungan kelapa sawit umur 6 tahun cahaya yang masuk melalui celah antar pohon dan daun lebih tinggi karena tutupan masih sedikit. Tanaman ini mampu tumbuh hingga tingkat naungan 90\% (Adetula 2004). Samedani et al. (2013) menyatakan $A$. gangetica merupakan tanaman yang mampu tumbuh dalam keadaan cahaya yang sedikit dan tanah yang tingkat kesuburannya rendah.

Tabel 2 Pengaruh jarak tanam dan umur naungan pada produksi biomassa tanaman A. gangetica (g)

\begin{tabular}{|c|c|c|c|}
\hline \multirow{2}{*}{ Jarak Tanam } & \multicolumn{2}{|c|}{ Umur Kelapa Sawit } & \multirow[b]{2}{*}{ Rataan } \\
\hline & 6 tahun & 8 tahun & \\
\hline $10 \times 10$ & $3225,33 \pm 726,83$ & $2307,00 \pm 1069,12$ & $2766,17 \pm 959,96^{a}$ \\
\hline $25 \times 25$ & $2023,67 \pm 464,31$ & $774,00 \pm 319,16$ & $1398,83 \pm 771,67^{b}$ \\
\hline $40 \times 40$ & $293,67 \pm 22,72$ & $123,00 \pm 7,00$ & $208,33 \pm 94,67^{c}$ \\
\hline Rataan & \multicolumn{3}{|c|}{$1847,56 \pm 1347,24^{a} 1068,00 \pm 1119,91^{b}$} \\
\hline
\end{tabular}

Superskrip yang berbeda pada kolom dan baris yang sama menunjukkan perbedaan nyata $(\mathrm{P}<0,05)$ 
Tabel 3 Pengaruh umur kelapa sawit terhadap kualitas nutrien tanaman A. gangetica

\begin{tabular}{clclll}
\hline Perlakuan & \multicolumn{3}{c}{ Kandungan Nutrien } \\
\cline { 2 - 6 } Jarak Tanam $(\mathrm{cm})$ & BK & Abu & LK & PK & SK \\
$10 \times 10$ & $10,94 \pm 2,09^{\mathrm{b}}$ & $14,62 \pm 1,82$ & $1,15 \pm 0,15$ & $16,44 \pm 1,87$ & $25,69 \pm 1,18^{\mathrm{a}}$ \\
$25 \times 25$ & $14,26 \pm 6,20^{\mathrm{a}}$ & $11,69 \pm 3,32$ & $0,98 \pm 0,18$ & $16,92 \pm 0,88$ & $21,79 \pm 0,96^{\mathrm{b}}$ \\
$40 \times 40$ & $16,52 \pm 13,34^{\mathrm{a}}$ & $13,19 \pm 3,62$ & $0,98 \pm 0,30$ & $17,32 \pm 1,71$ & $19,78 \pm 2,74^{\mathrm{c}}$ \\
\hline Umur Sawit & & & & & \\
6 tahun & $7,57 \pm 2,32^{\mathrm{b}}$ & $13,30 \pm 2,86$ & $0,91 \pm 0,22^{\mathrm{b}}$ & $17,57 \pm 1,02$ & $21,74 \pm 3,48^{\mathrm{a}}$ \\
8 tahun & $20,25 \pm 7,34^{\mathrm{a}}$ & $13,03 \pm 2,98$ & $1,15 \pm 0,25^{\mathrm{a}}$ & $16,22 \pm 1,91$ & $23,10 \pm 2,55^{\mathrm{a}}$ \\
\hline
\end{tabular}

Superskrip yang berbeda pada kolom yang sama menunjukkan perbedaan nyata $(P<0,05)$

\section{Kualitas Nutrien}

Pakan hijauan yang baik memiliki kandungan protein yang tinggi dan produksi yang mampu mencukupi kebutuhan ternak serta mampu dibudidayakan. Hasil penelitian ini menunjukkan bahwa pada naungan umur 8 tahun memberikan pengaruh yang nyata $(\mathrm{p}<0,05)$ terhadap kandungan bahan kering (BK) A. gangetica jika dibandingkan dengan naungan kelapa sawit umur 6 tahun (Tabel 3). Semakin tua umur naungan kelapa sawit semakin tingggi bahan kering yang dihasilkan. Tanaman yang memiliki dinding sel yang tinggi maka bahan kering dari tanaman ini juga akan tinggi (Savitri et al. 2012). Naungan umur 8 tahun memberikan pengaruh yang nyata $(p<0,05)$ terhadap kadar lemak kasar, jika dibandingkan dengan naungan kelapa sawit umur 6 tahun.

Naungan kelapa sawit dengan umur 6 tahun memiliki pengaruh yang nyata $(p<0,05)$ terhadap kadar serat kasar (SK) dibandingkan naungan umur 8 tahun (Tabel 3). Hal ini disebabkan karena pada umur 6 tahun tingkat intensitas cahaya yang diperoleh lebih tinggi daripada umur 8 tahun. Semakin tua umur kelapa sawit maka naungannya juga akan semakin tinggi. Untuk kadar nutrien lainnya seperti protein kasar (PK) dan abu perbedaan umur naungan tidak memiliki pengaruh yang nyata. Hal ini diduga umur panen yang sama dan intensitas cahaya yang diperoleh tidak sepenuhnya diubah untuk metabolisme tanaman. Menurut Bonner (1965) bahwa cahaya yang dihasilkan dengan tingkat naungan 70\% tidak mampu mengubah nitrogen utama ke

Tabel 4 Pengaruh jarak tanam dan umur naungan pada kadar serat tanaman A. gangetica (g)

\begin{tabular}{llcl}
\hline \multirow{2}{*}{ Jarak Tanam } & \multicolumn{2}{c}{ Umur Kelapa Sawit } & \\
\cline { 2 - 3 } ADF & 6 tahun & 8 tahun & Rataan \\
$10 \times 10$ & $35,01 \pm 3,81$ & $37,67 \pm 1,64$ & $36,34 \pm 3,00$ \\
$25 \times 25$ & $34,39 \pm 1,78$ & $36,58 \pm 3,19$ & $35,49 \pm 2,60$ \\
$40 \times 40$ & $37,25 \pm 2,26$ & $31,99 \pm 1,29$ & $34,62 \pm 3,23$ \\
\hline Rataan & $35,55 \pm 2,72$ & $35,41 \pm 3,23$ & \\
\hline NDF & & & \\
$10 \times 10$ & $41,40 \pm 3,89$ & $43,88 \pm 1,97$ & $42,64 \pm 3,07$ \\
$25 \times 25$ & $40,85 \pm 1,98$ & $43,32 \pm 3,02$ & $42,09 \pm 2,65$ \\
$40 \times 40$ & $45,24 \pm 4,89$ & $38,81 \pm 1,99$ & $42,03 \pm 4,85$ \\
\hline Rataan & $42,50 \pm 3,88$ & $42,00 \pm 3,16$ & \\
\hline
\end{tabular}

nitrogen organik untuk metabolisme tanaman. Kandungan nitrogen pada naungan $70 \%$ lebih tinggi dibandingkan pada naungan 0\% (Pradnyawan et al. 2005).

Pada perlakuan jarak tanam diperoleh hasil bahwa kandungan bahan kering $(\mathrm{BK})$ terbaik $(\mathrm{p}<0,05)$ terdapat pada perlakuan $25 \times 25 \mathrm{~cm}$ dan $40 \times 40 \mathrm{~cm}$ dibandingkan dengan perlakuan $10 \times 10 \mathrm{~cm}$ (Tabel 3). Jarak tanam yang lebih lebar terdapat tingkat persaingan tanaman lebih rendah sehinga produksi bahan kering (BK) akan meningkat. Menurut Borghi et al. (2012), jika tanaman berada dibawah naungan akan menghambat proses fotosintesis yang berakibat pada turunnya produksi biomassa berupa bahan kering. Pada jarak tanam $10 \times 10 \mathrm{~cm}$ berpengaruh nyata $(\mathrm{p}<0,05)$ terhadap kandungan serat kasar (SK) jika dibandingkan dengan perlakuan $25 \times 25 \mathrm{~cm}$ dan $40 \times 40 \mathrm{~cm}$ (Tabel 3).

Semakin tinggi nilai Acid Detergent Fiber (ADF) dan Neutral Detergent Fiber (NDF) maka nilai kecernaan pakan tersebut semakin tinggi (Preston \& Leng 1987). Hasil penelitian ini menunjukkan bahwa jarak tanam tidak memiliki pengaruh yang nyata terhadap kadar ADF dan NDF A. gangetica (Tabel 4). Hal ini diduga kerena pada jarak tersebut tanaman ini masih memiliki struktur yang lunak sehingga kandungan ADF dan NDF tidak memiliki perbedaan yang nyata. Menurut Sudirman et al. ( 2015) bahwa kadar NDF dan ADF akan tinggi jika tanaman itu memiliki batang yang keras.

\section{SIMPULAN}

A. gangetica dapat tumbuh dengan baik di bawah naungan kelapa sawit umur 6 tahun dibandingkan dengan umur 8 tahun. Produksi terbaik terdapat pada jarak tanam 10x10 $\mathrm{cm}$ pada umur 6 tahun. Sedangkan untuk kualitas nutrien yang terbaik terdapat pada jarak tanam $40 \mathrm{x} 40 \mathrm{~cm}$.

\section{DAFTAR PUSTAKA}

\footnotetext{
Adetula OA. 2004. Asystasia gangetica (L.) Anderson. Record from PROTA4U. Grubben GJH and Denton OA (Editors). PROTA (Plant Resources of Tropical Africa /Ressources végétales de l'Afrique tropicale). Wageningen (NL). www.prota4u.org/search.asp.
} 
Alvarez CGD, Pinho RG \& Borges ID.2006. Evaluation of agronomic characteristics and production of forage and grains of corn in different densities of sowing and row spacings. Ciência \& Agrotecnologia. 30 (3) : 402-408. doi:10.1590/S141370542006000300003

Andrieu N, Vayssières J, Corbeels M, Blanchard M, Vall E \&Tittonell P. 2015. From farm scale synergies to village scale trade-offs: cereal crop residues use in an agro-pastoral system of the Sudanian zone of Burkina Faso. Agricultural System. 134(C): 84-96.

AOAC. 2005. Official Methods of Analysis. of AOAC International. The 8th Edition. Maryland (US): AOAC International.

Asbur Y, Yahya S, Murtilaksono K, Sudrajat \& Sutarta ES. 2015. The role of cover crop against nutrient balance at mature oil palm plantation at South Lampung. International Journal of Sciences : Basic and Applied Research. 23: 53-60.

Asbur Y, Yahya S, Murtilaksono K, Sudrajat \& Sutarta ES. 2016. The roles of Asystasia gangetica (T) Anderson and ridge terrace in reducing soil erosion and nutrient losses in oil palm plantation in South Lampung, Indonesia.Journal of Tropical Crop Science. 3 (2) :49-55.

Banurea DP, Abdullah L \& Kumalasari NR. 2017. Evaluasi produksi biomassa dan karakteristik tajuk Indigofera zollingiriena pada jarak tanam yang berbeda. Buletin Makanan Ternak. 104 (2) : 1 11.

Bonner, J.1965. Plant Biochemistry. New York: Academic Press.

Borghi E, Crusciol CAC, Nascente AS, Mateus GP, Martins PO \& Costa C. 2012. Effects of row spacing and intercrop on maize grain yield and forage production of palisade grass. Crop \& Pasture Science. CSIRO Publishing.

Daru P Taufan, Yulianti A \&Widodo E. 2013. Potensi hijauan di perkebunan kelapa sawit sebagai pakan sapi potong di Kabupaten Kutai Kartanegara. Pastura. 3 (2): 94 - 98.

Demétrio CS, Fornasieri Filho D, Cazetta JO \& Cazetta DA. 2008. Performance of maize hybrids submitted to different row spacing and population densities. Pesquisa Agropecuaria Brasileira. 43 (12): 1691-1697.

Direktorat Jenderal Perkebunan. 2016. Statistik Perkebunan Sawit Kelapa Sawit. Jakarta.

Goering HK, Van Soest PJ. 1970. Forage fiber analysis (appartus, reagents, procedures and some application). US Department of Agriculture Handbook

Gopal TK, Megha G, Chamundeeswari D \& Umamaheswara RC. 2013. Phytochemical and pharmacological studies on whole plant of Asystasia gangetica. Indian Journal of Research in Pharmacy and Biotechnology. 1(3): 365-370.

Homann-Kee Tui S, Valbuena D, Masikati P, Descheemaeker K, Nyamangara J, Claessens L, Erenstein O,Van Rooyen A \& Nkomboni D. 2015. Economic trade-offs of biomass use in croplivestock systems: exploring more sustainable options in semiarid Zimbabwe. Agricultural System. 134:48-60.

Karima SS, Nawawi M \& Herlina N. 2013. Pengaruh saat tanam jagung dalam tumpangsari tanaman jagung (Zea mays L.) dan brokoli (Brassica oleracea L. var. botrytis). Jurnal Produksi Tanaman. 1(3) : 87-92

Kumalasari NR, Wahyuni L \& Abdullah L. 2018. Germination of Asystasia gangetica seeds exposed to different source, color, size, storage duration and pre-germinative treatments. Di dalam : Sudarman A, Takahashi J, Pitchford W, Ludema MW, Lozicki A, Despal, editor. Sustainable Animal Production for Food Security and Safety. The 4th International Seminar on Animal Industry [Internet]. 2018 August 28-30; Bogor (ID). Hlm 130-134

Mattjik AA \& Sumertajaya IM. 2013. Perancangan Percobaan dengan Aplikasi SAS dan Minitab. IPB Press. Bogor.

Mugabo R \& Raji IA. 2013. Effects of aqueous leaf extract of Asystasia gangetica on the blood pressure and heart rate in male spontaneously hypertensive wistar rats. BMC Complementary and Alternative Medicine.13(283): 1-7.

Preston, T R \& Leng RA. 1987. Matching Ruminant Production System with Available Resources in the Tropics and Sub-tropics. Penambul Books, Armidale, Australia. Pp 161-180.

Priwiratama H. 2011. Informasi organisme tanaman pengganggu ; Asystasia gangetica (L.) subsp. Micrantha (Nees). Pusat Penelitian Kelapa Sawit. G-0001:1-2.
Pradnyawan, S.W.H., W. Mudyantini, Marsusi. 2005. Pertumbuhan, kandungan nitrogen, klorofil dan karotenoid daun Gynura procumbens [Lour] Merr. pada tingkat naungan berbeda. Biofarmasi. 3:7-10.

Samedani B, Juraimi AS, Anwar MP,Rafii MY, Awadz SH \& Anuar AR. 2013. Competitive interaction of Axonopus compressus and Asystasia gangetica under contrasting sunlight intensity. The Scientific World Journal. $2013: 1-8$

Sandoval JR \& Rodriguez PA. 2012. Asystasia gangetica (Chinese violet). Washington DC (US): Department of Botany-Smithsonian NMNH.

Sari DM, Sembodo DR \& Hidayat KF. 2016. Pengaruh jenis dan tingkat kerapatan gulma terhadap pertumbuhan awal tanaman ubikayu (Manihot esculenta Crantz) klon Uj-5 (Kasetsart). Jurnal Agrotek Tropika.4(1): 1-6.

Savitri MV, Sudarwati H \& Hermanto. 2012. Pengaruh umur pemotongan terhadap produktivitas gamal (Gliricidia sepium). Jurnal Ilmu Ilmu Pertanian 23(2) : 25-35

Sudirman, Suhubdy S, Hasan. SD, Dilaga SH \& Karda. I W. 2015 Kandungan Neutral (Detergent Fibre (NDF) dan Acid Detergent Fibre (ADF) Bahan Pakan Lokal Ternak Sapi yang Dipelihara pada Kandang Kelompok. Jurnal Ilmu Teknologi Peternakan Indonesia.1(1): 77-81.

Van soest PJ, Robertson JB \& Lewis BA. 1991. Methods for dietary fiber neutral detergent fiber, and non-starch polysaccharides in relation to animal nutrition.Journal of Dairy science. 70: 2063. 